\title{
Phytic acid, inorganic phosphorus, antioxidants in bread and durum wheat and their associations with agronomic traits
}

\author{
Gordana Branković ${ }^{1}$, Vesna Dragičević ${ }^{2}$, Dejan Dodig², Desimir Kneževićc ${ }^{3}$ Vesna Kandić ${ }^{2}$, Gordana Šurlan-Momirović ${ }^{1}$, \\ Mile Sečanski \\ ${ }^{1}$ University of Belgrade, Faculty of Agriculture, Department of Genetics, Plant Breeding and Seed Science, Nemanjina 6, 11000, \\ Belgrade, Serbia \\ ${ }^{2}$ Maize Research Institute "Zemun Polje", Slobodana Bajića 1, 11185, Belgrade, Serbia \\ ${ }^{3}$ University of Priština, Faculty of Agriculture, Jelene Anžujske bb, 38228 Zubin Potok, Serbia \\ e-mail: gbrankovic@agrif.bg.ac.rs
}

\begin{abstract}
The phytic acid (PA), inorganic phosphorus $\left(\mathrm{P}_{\mathrm{i}}\right)$, yellow pigment (YP), water soluble phenolics (WSPH) and free protein sulfhydryl groups (PSH) of 15 Triticum aestivum and 15 Triticum durum wheats grown at six different environments were evaluated for variability, intra- and inter- relations with agronomic traits. The most variable properties in bread wheat were YP and WSPH with coefficients of variation (CV) amounting to $14.59 \%$ and $14.10 \%$, respectively, while in durum wheat those were PSH and YP with CV of $17.59 \%$ and $15.02 \%$, respectively. PA in durum wheat showed the least variability (CV 3.61\%). Among others, positive associations were obtained between WSPH and YP in bread and durum wheat, YP and PSH, WSPH and PSH, yield (YLD) and WSPH, YLD and PSH in durum wheat, while negative associations were recorded for PA and YP, PA and WSPH, YLD and antioxidants (YP and WSPH) in bread wheat, PA and antioxidants, PA and YLD in durum wheat.
\end{abstract}

Key words: Triticum aestivum, Triticum durum, phytochemicals, multi-environment trial, variability, selection

\section{Introduction}

Wheat is eurytopic plant species with prominent polymorphism, due to wide area of cultivation, from $67^{\circ} \mathrm{N}$ in Norway, Finland and Russia to $45^{\circ} \mathrm{S}$ in Argentina (Peng et al. 2011). Approximately, 95\% of wheat species cultivated worldwide are represented by hexaploid common wheat (Triticum aestivum L.), exploited for making bread, cookies and pastries, whereas the biggest part of the remaining $5 \%$ is tetraploid durum wheat (Triticum durum Desf.), used for making pasta, couscous, unleavened bread, bulgur and mote (Shewry 2009).

The increasing request of more nutritious and functional wheat products with increased health beneficial effects for disease prevention will direct future breeding programmes (Shewry and Ward 2012). Phytic acid (myo-inositol $[1,2,3,4,5,6]$-hexakisphosphate [InsP6]) (PA) represents an antinutritional factor, since as a polyvalent anion chelates important micronutrients such as magnesium, calcium, zinc, iron, manganese and copper, in the form of mixed salts phytates. Such a form is excreted by humans and monogastric animals leading to their deficiency in the diet (Lonnerdal 2002). Furthermore, the excessive phosphorus excreted in animal waste causes eutrophication of waters, representing a significant problem in Europe and North America (Lott et al. 2000). PA binds 65-85\% of the total phosphorus of cereal seed and acts as a bottle-neck in the flux of phosphorus in agro-ecosystems (Raboy 2001). The PA content in plants varies dependently on the stage of maturity, genotype, climatic factors and location (Singh, 2008). Branković et al. (2015) found that a major source of variation for the PA content was a genotype $\times$ environment interaction (GEI), followed by genotype $(G)$ and then environment $(E)$ for bread wheat, and the $\mathrm{E}, \mathrm{GEI}$, and $\mathrm{G}$, in descending order, for durum wheat.

Wheat naturally contains various classes of antioxidants with health-beneficial effects (Zhou and Yu 2004, Dykes and Rooney 2007). Yellow pigment (YP) is an essential factor for the quality of durum wheat grains for processing into pasta. It is defined as the content of carotenoids extracted from endosperm and is expressed as $\beta$-carotene content (mg) per 100g of dry matter. Their photo-protective role enables correct assembly of the light-harvesting complexes (Graham and Rosser 2000). As antioxidants they limit oxidative damage (Cuttriss et al. 2006), $\beta$-carotene acts as a precursor of vitamin A (Yeum and Russell 2002), and lutein and zeaxanthin have been associated with the prevention of age-related macular degeneration and cataracts (Landrum and Bone 2004). According to Clarke et al. (2006) and Blanco et al. (2011) the estimate of broad-sense heritability of yellow pigment concentration was high for durum wheat (0.78-0.96). Branković et al. (2015) observed the same hierarchy of importance of the sources of variation influencing total yellow pigment: G > GEI > E for both bread and durum wheat. 
Phenolic compounds act as free radical scavengers and exhibit antioxidant, antimutagenic, antimicrobial and anti-inflammatory effects (Drankhan et al. 2003, Žilić et al. 2009). Phenolics reduce oxidation of low density lipoproteins and prevent atherosclerosis (Meyer et al. 1998), the risk of chronic diseases (Kim et al. 2003) and cancer by decreasing oxidative stress (Drankhan et al. 2003). Free sulfhydryl groups of proteins (PSH) play an important role in plants as antioxidants (Chernikova et al. 2000), quenching free radicals and preventing the effects of stress (Vieira Dos Santos and Rey 2006), reducing the trypsin inhibitors such as the Kunitz trypsin inhibitor (Kobrehel et al. 1991), taking part in the detoxification, signal transduction and apoptosis (Prakash et al. 2009), and acting as integral parts of the cell regulatory redox system (Leustek et al. 2000). Decreased levels of thiols are noted in various medical disorders (Adams et al. 1991, Prakash et al. 2009). Several authors found environment to be more important than genotype and their interaction in variation of WSPH and PSH contents in both bread and durum wheat (Moore et al. 2006, Mpofu et al. 2006, Hadži Tašković Šukalović et al. 2013, Branković et al. 2015)

Correlations between antinutrients and antioxidants are of a particular importance, but there is lack of literature data, and their relationship is to a large extent unexplored. A response to the breeding for quality traits depends on genetic variance and heritability of the trait of interest, but also on the possible undesirable correlations with important agronomic properties such as grain yield and yield components. The aim of the present study was to assess variability of the content of phytic acid as antinutrient, inorganic phosphorus and antioxidants in different bread and durum wheat genotypes, as well as to point out the correlations among them and with agronomic traits. This will contribute to the purpose of developing wheat cultivars with improved nutritional and functional quality, and will be useful for the evaluation of the possibility of indirect selection.

\section{Material and methods}

\section{Plant material and experimental design}

The plant material used for multi-environment trial consisted of 15 bread wheat (Triticum aestivum L. ssp. aestivum) and of 15 durum wheat (Triticum durum Desf.) genotypes. All wheat genotypes were drawn from the gene banks of the Institute of Field and Vegetable Crops in Novi Sad and Maize Research Institute, Zemun Polje, both in Serbia. The names, codes, countries of origin, growth type and pedigree of used genotypes are listed in Supplementary Table 1. The field trials were carried out in the Institute of Field and Vegetable Crops at the Rimski Šančevi (RS) ( $\left.45^{\circ} 19^{\prime} 51^{\prime \prime} \mathrm{N} ; 19^{\circ} 50^{\prime} 59^{\prime \prime} \mathrm{E}\right)$, Maize Research Institute, Zemun Polje, in Zemun Polje (ZP) (4452’ N; $\left.20^{\circ} 19^{\prime} \mathrm{E}\right)$ and PKB - Agricultural Corporation Belgrade, Agroeconomik Institute in Padinska Skela (PS) $\left(44^{\circ} 57^{\prime} \mathrm{N} 20^{\circ} 26^{\prime} \mathrm{E}\right.$ ), all in Serbia, during two growing seasons 2010-2011 (11) and 2011-2012 (12). These field trials were set as randomised complete block design with four replications. The experimental plot consisted of 5 rows of $1 \mathrm{~m}$ in length with the inter-row spacing of $0.2 \mathrm{~m}$. The basic plot consisted of 3 inner rows of $0.6 \mathrm{~m}^{2}(3 \times 0.2 \times 1 \mathrm{~m})$ and plant material within it was used for the analyses. According to IUSS Working Group WRB (2006), haplic chernozem (CHha) is the type of the soil at the RS and ZP locations, while humic gleysol (GLhu) is predominant in PS. A total of $45 \mathrm{~kg}$ nitrogen (N) ha- ${ }^{-1}, 45 \mathrm{~kg}$ phosphorus $(\mathrm{P}) \mathrm{ha}^{-1}$ and $45 \mathrm{~kg}$ potassium (K) ha-1 were applied in PS11 and PS12, while 18 $\mathrm{kg} \mathrm{N} \mathrm{ha}^{-1}$ and $78 \mathrm{~kg} \mathrm{P} \mathrm{ha}^{-1}$ were applied prior to sowing in the ZP11, ZP12, RS11 and RS12. These rates were recommended on the basis of analyses of soil chemical properties and available amounts of $\mathrm{P}, \mathrm{K}$ and $\mathrm{N}$ in the soil. Sowing in both years was done mechanically in RS in mid-October and by hand in PS and ZP in late October and early November, respectively. In spring, with top dressing $46 \mathrm{~kg} \mathrm{~N}^{-1}$ were applied in PS11 and PS12, $92 \mathrm{~kg} \mathrm{~N} \mathrm{ha-1}^{-1}$ in ZP12, $54 \mathrm{~kg} \mathrm{~N} \mathrm{ha}^{-1}$ in ZP11, and $51 \mathrm{~kg} \mathrm{~N} \mathrm{ha}^{-1}$ in RS11 and RS12. Integral protection against pests and weeds was accomplished by the proper use of adequate pesticides, its efficacy was monitored, and crop damages were avoided.

\section{Agronomic traits}

Measurements of agronomic traits were performed across all four replications and the obtained values are given in Supplementary table 2. Plots were hand-harvested at maturity, and grain yield (YLD) was determined per basic plot and expressed as $\mathrm{kg} \mathrm{ha}^{-1}$. Plant height $(\mathrm{PH})$ and spike length $(\mathrm{SL})$ were measured on 20 representative plants per basic plot and expressed in cm. Number of grains per spike (GNS) was determined on the 20 representative spikes per basic plot. Thousand grain weight (g) (TGW) was determined from the harvested grain as three samples of 1000 grains per replication per basic plot. The grain length (GL), grain width (GW) and grain thickness (GT) were measured by digital electronic micrometer from the samples of twenty grains per replication and expressed in $\mathrm{mm}$. The productive tillering coefficient (PTC) was determined as a ratio of the number of spikes in the stage of maturation and the number of overwintered plants counted in the spring at the elementary plot per each repetition. 


\section{Analyses of chemical properties}

For the purpose of analysing the chemical properties, grains were ground in the Laboratory Mill 120 Perten (Perten, Sweden) and flour with particles size $<500 \mu \mathrm{m}$ was produced. Chemical properties were determined spectrophotometrically with the Shimadzu UV-1601 spectrophotometer (Shimadzu Corporation, Japan) as detailed in the following paragraphs. All analysed chemical characteristics were determined in four replications and were expressed on the dry mass (DM) basis.

\section{Determination of phytic acid (PA) and inorganic phosphorus $\left(P_{i}\right)$ content}

The contents of PA and $\mathrm{P}_{\mathrm{i}}$ were determined by the method given by Dragičević et al. (2011). Flour was extracted with $5 \%$ trichloroacetic acid and then centrifuged at $12.000 \mathrm{rpm}$ for $15 \mathrm{~min}$ at $4{ }^{\circ} \mathrm{C}$. Wade reagent (prepared from $\mathrm{FeCl}_{3} \times 6 \mathrm{H}_{2} \mathrm{O}$ and 5-sulphosalicylic acid) was added to $1.5 \mathrm{~mL}$ of supernatant and then absorbance was read at $\lambda=$ $500 \mathrm{~nm}$. $P_{i}$ was determined from the same extract by adding the reagent prepared from ammonium heptamolybdate and ammonium metavanadate, and absorbance was then read at $\lambda=400 \mathrm{~nm}$. The phytate phosphorus $\left(P_{p}\right)$ content was obtained by dividing the value of PA by a factor of 3.55 (Barac et al. 2006) and consequently phytic phosphorus/inorganic phosphorus $\left(\mathrm{P}_{\mathrm{p}} / \mathrm{P}_{\mathrm{i}}\right)$ relation was estimated.

\section{Quantification of water soluble phenolics (WSPH)}

The water soluble phenolics content was determined by the method of Simić et al. (2004) and expressed in $\mu \mathrm{g}$ of ferulic acid equivalent (FAE). Flour was extracted with double-distilled water and then centrifuged at $12000 \mathrm{rpm}$ for $15 \mathrm{~min}$ at $4{ }^{\circ} \mathrm{C}$. Furthermore, $0.05 \mathrm{M} \mathrm{FeCl}_{3}$ in $0.1 \mathrm{M} \mathrm{HCl}$ and $0.008 \mathrm{M} \mathrm{K}_{3} \mathrm{Fe}(\mathrm{CN})_{6}$ were added to the sample solution, and after $25 \mathrm{~min}$ the absorbance was measured at $\lambda=722 \mathrm{~nm}$.

\section{Quantification of yellow pigment (YP)}

Total YP was determined by the AACC (American Association of Cereal Chemists [1995]) method. Ground samples of $8 \mathrm{~g}$ were extracted with $40 \mathrm{ml}$ of water-saturated 1-butanol. The sample was homogenised for $60 \mathrm{~s}$, allowing to stand for $20 \mathrm{~min}$ at room temperature, and further homogenised for $30 \mathrm{~s}$. The mixture was centrifuged at 5000 rpm for $10 \mathrm{~min}$, and the absorbance of supernatant was recorded at $435 \mathrm{~nm}$. The total YP content was calculated using the conversion factor of 1.6632 and expressed as $\mu \mathrm{g}$ of $\beta$-carotene equivalent ( $\beta C E)$ per g.

\section{Quantification of free protein sulfhydryl groups (PSH)}

The free protein sulfhydryl groups (PSH) content was determined by the method of de Kok et al. (1981) from the same extract used for phenolics determination. Then, $0.2 \mathrm{M}$ potassium phosphate buffer $(\mathrm{pH}=8.0)$ and $10 \mathrm{mM}$ DTNB (5.5'-dithio-bis-(2-nitrobenzoic acid)) were added to the extract, and the absorbance was measured at $\lambda=415 \mathrm{~nm}$.

\section{Statistical analyses}

Two-way fixed combined ANOVA, based on the random complete block design (RCBD), with the effects of genotype and environment as fixed ones, was used. Environment represented year $\times$ location combination. The Tukey (HSD) test was applied to find means of chemical and agronomic properties of genotypes that were significantly different from each other. Testing the difference in characteristics means between bread and durum wheat was carried out using $t$-test. The correlation analysis included Pearson's correlation coefficients. ANOVA, Tukey (HSD) test and Pearson's correlation coefficients were calculated by the use of the STATISTICA 9.0. (Statsoft 2009). The genotype-by-trait (GT) biplot (Yan and Rajcan 2002) was created within the R computing environment (R Development Core Team 2013), and was used to visualise associations of agronomic traits, PA and antioxidants, and also genotypes traits profiles.

\section{Results and discussion \\ Variability of $P A$ and $P_{i}$}

The PA content ranged from 14.21 to $17.86 \mathrm{mg} \mathrm{g}^{-1}$ for bread wheat genotypes and from 14.63 to $16.78 \mathrm{mg} \mathrm{g}^{-1}$ for durum wheat genotypes (Table 1). Individually, the bread wheat genotypes with the lowest PA levels were ZP 87/Ip and ZP AU 12 (14.21 and $14.65 \mathrm{mg} \mathrm{g}^{-1}$, respectively), which originated from Serbia and Macedonia, respectively. The lowest PA values for genotypes of durum wheat were recorded in ZP 120/I and 37ED. 7896 (14.63 and 15.26 $\mathrm{mg} \mathrm{g}^{-1}$, respectively). 
Table 1. Phytic acid, inorganic phosphorus and antioxidants of bread and durum wheat genotypes represented as mean values across six environments

\begin{tabular}{|c|c|c|c|c|c|c|}
\hline Genotype & PA $\left(m g g^{-1}\right)$ & $\begin{array}{c}\mathrm{P}_{\mathrm{i}} \\
\left(\mathrm{mg} \mathrm{g}^{-1}\right)\end{array}$ & $\mathrm{P}_{\mathrm{p}} / \mathrm{P}_{\mathrm{i}}$ & $\mathrm{YP}\left(\mu \mathrm{g} \beta C E \mathrm{~g}^{-1}\right)$ & $\begin{array}{l}\text { WSPH ( } \mu \mathrm{g} \\
\left.\text { FAE g }^{-1}\right)\end{array}$ & $\begin{array}{c}\text { PSH (nmol } \\
\left.\mathrm{g}^{-1}\right)\end{array}$ \\
\hline \multicolumn{7}{|c|}{ Triticum aestivum L. ssp. aestivum (bread wheat) } \\
\hline Žitarka & $16.23^{\mathrm{feg}}$ & $0.470^{b}$ & $9.92^{j}$ & $3.14^{f}$ & $1095.67^{c}$ & 87.61 ecd \\
\hline Stephens & $15.44^{h}$ & $0.458^{c}$ & $10.04^{i j}$ & $4.48^{b}$ & $1347.39^{a}$ & $89.18^{c d}$ \\
\hline Renan & $16.04^{\mathrm{g}}$ & $0.430^{d}$ & $10.73^{g}$ & $3.44^{\mathrm{e}}$ & $1056.34^{d}$ & 86.43 ed \\
\hline Caldwell & $17.86^{a}$ & $0.475^{b}$ & $10.74 \mathrm{~g}$ & $4.00^{c}$ & $930.688^{g f}$ & $97.44^{\text {ba }}$ \\
\hline Abe & $17.43^{b}$ & $0.562^{a}$ & $8.96^{k}$ & $3.54^{\mathrm{e}}$ & $1036.29^{d}$ & $91.10^{\mathrm{bcd}}$ \\
\hline Auburn & $16.83^{d}$ & $0.445^{d}$ & $10.98^{\mathrm{gf}}$ & $3.79^{d}$ & $1102.53^{c}$ & 93.94 bc \\
\hline Frankenmuth & $16.24^{\mathrm{fe}}$ & $0.410^{\mathrm{e}}$ & $11.20^{f}$ & $4.03^{c}$ & $1173.83^{b}$ & $93.81 \mathrm{bc}$ \\
\hline Apache & $14.88^{i}$ & $0.415^{e}$ & 10.19 in & $5.29^{a}$ & $1156.69^{b}$ & $87.47^{\text {ecd }}$ \\
\hline ZP AU 12 & $14.65^{\mathrm{ji}}$ & $0.409^{f}$ & $10.42^{h}$ & $3.89 \mathrm{dc}$ & $987.41^{\mathrm{e}}$ & 80.95 ef \\
\hline Marija & $15.60^{h}$ & $0.453^{c}$ & $9.94^{\mathrm{ij}}$ & $4.58^{b}$ & $728.02^{h}$ & 85.72 efd \\
\hline ZP 87/lp & $14.21^{\mathrm{j}}$ & $0.335^{i}$ & $12.52^{b}$ & $3.87^{\mathrm{dc}}$ & 984.52 e & $87.13^{\text {ecd }}$ \\
\hline Tecumseh & $17.20^{\mathrm{c}}$ & $0.431^{d}$ & $11.53^{\mathrm{e}}$ & $3.48^{e}$ & $934.87^{f}$ & $102.23^{a}$ \\
\hline Pobeda & $16.42^{\mathrm{e}}$ & $0.342^{h}$ & $13.66^{a}$ & $3.49^{e}$ & $918.86^{\mathrm{gf}}$ & $78.95^{f}$ \\
\hline Zemunska rosa & $15.67^{h}$ & $0.388^{\mathrm{g}}$ & $11.85^{d}$ & $3.80^{d}$ & $995.95^{\mathrm{e}}$ & $93.89 \mathrm{bc}$ \\
\hline Ludwig & $16.04^{\mathrm{fg}}$ & $0.388^{\mathrm{g}}$ & $12.15^{c}$ & $3.24^{f}$ & $899.83^{\mathrm{g}}$ & $88.23^{\mathrm{cd}}$ \\
\hline Mean & $16.05^{\mathrm{A}}$ & $0.427^{A}$ & $10.99^{A}$ & $3.87^{\mathrm{A}}$ & $1023.26^{\mathrm{A}}$ & $89.61^{A}$ \\
\hline CV (\%) & 6.40 & 13.09 & 10.95 & 14.59 & 14.10 & 6.72 \\
\hline Min & 14.21 & 0.335 & 8.96 & 3.14 & 728.02 & 78.95 \\
\hline Max & 17.86 & 0.562 & 13.66 & 5.29 & 1347.39 & 102.23 \\
\hline \multicolumn{7}{|c|}{ Triticum durum Desf. (durum wheat) } \\
\hline 37ED.7922 & $15.30^{\mathrm{h}}$ & $0.383^{f}$ & $11.55^{\mathrm{de}}$ & $5.32^{a}$ & $884.10^{i}$ & 87.48 egf \\
\hline 37ED.7896 & $15.26^{h}$ & $0.426^{d c}$ & $10.51^{g}$ & $4.82^{c}$ & $1074.18^{b}$ & $95.56^{d}$ \\
\hline 37ED.7817 & $15.47^{\mathrm{gh}}$ & $0.476^{b}$ & $9.57^{i}$ & $4.24^{\mathrm{ed}}$ & $994.34 \mathrm{fe}$ & $49.20^{i}$ \\
\hline Varano & $16.40^{\mathrm{bc}}$ & $0.499^{\text {a }}$ & $9.64^{i}$ & $3.78^{g}$ & 1007.21 de & $73.18^{h}$ \\
\hline 37ED.7821 & $16.37^{d c}$ & $0.467^{b}$ & $10.19^{h}$ & $4.05^{e f}$ & $974.80^{\mathrm{fg}}$ & $86.75^{\mathrm{gf}}$ \\
\hline 37ED.7880 & $16.06^{\mathrm{e}}$ & $0.312^{h}$ & $14.65^{a}$ & $4.21^{\mathrm{ed}}$ & 1011.59 de & $84.80^{\mathrm{g}}$ \\
\hline ZP 10/I & $16.20^{\text {dce }}$ & $0.426^{d c}$ & $11.12^{f}$ & $4.16^{\mathrm{ef}}$ & $1023.21^{d c}$ & $108.57^{b}$ \\
\hline SOD 55 & $16.78^{a}$ & $0.405^{\mathrm{e}}$ & $12.09^{c}$ & $3.48^{h}$ & $920.15^{h}$ & $108.50^{b}$ \\
\hline 37ED./07 7803 & $15.71^{f}$ & $0.392^{\mathrm{fe}}$ & $11.63^{d}$ & $5.01^{b}$ & $912.37^{h}$ & $92.37^{\text {ed }}$ \\
\hline DSP 66 & $16.11^{\text {de }}$ & $0.371^{\mathrm{g}}$ & $12.39^{b}$ & $3.49^{h}$ & $918.18^{h}$ & $93.13^{d}$ \\
\hline ZP 34/I & $16.61^{\text {ba }}$ & $0.401^{\mathrm{e}}$ & $11.83^{d c}$ & $3.05^{i}$ & $949.56^{\mathrm{g}}$ & $91.83^{\text {edf }}$ \\
\hline 37ED.7820 & $15.99^{\mathrm{e}}$ & $0.467^{b}$ & $9.98^{h}$ & $4.89^{c b}$ & $1030.31^{d c}$ & $105.10^{\mathrm{cb}}$ \\
\hline 37ED./07 7857 & $16.08^{e}$ & $0.429^{c}$ & $11.27^{\mathrm{fe}}$ & $4.39^{d}$ & $1045.94^{c}$ & $103.83^{\mathrm{cb}}$ \\
\hline 37ED./07 7849 & $15.65^{\mathrm{gf}}$ & $0.410^{d}$ & $11.13^{f}$ & $3.98^{f}$ & $1113.44^{a}$ & $102.43^{c}$ \\
\hline ZP 120/I & $14.63^{i}$ & $0.410^{d}$ & $10.09^{h}$ & $4.75^{c}$ & $1124.21^{\mathrm{a}}$ & $114.58^{a}$ \\
\hline Mean & $15.91^{\mathrm{A}}$ & $0.418^{A}$ & $11.18^{\mathrm{A}}$ & $4.24^{\mathrm{A}}$ & $998.91^{\mathrm{A}}$ & $93.15^{\mathrm{A}}$ \\
\hline CV (\%) & 3.61 & 11.23 & 11.75 & 15.02 & 7.32 & 17.59 \\
\hline Min & 14.63 & 0.312 & 9.57 & 3.05 & 884.10 & 49.20 \\
\hline Max & 16.78 & 0.499 & 14.65 & 5.32 & 1124.21 & 114.58 \\
\hline
\end{tabular}

Data are averages from six replicates. Mean values in each column labelled with the same lowercase letter are not significantly different $(p<0.05)$ based on the Tukey (HSD) test. Means with the same uppercase letter are not significantly different between wheat species according to the t-test $(p<0.05) . \mathrm{CV}=$ coefficient of variation; $\mathrm{PA}=$ phytic acid; $\mathrm{P}_{\mathrm{i}}=$ inorganic phosphorus; $\mathrm{P}_{\mathrm{p}} / \mathrm{P}_{\mathrm{i}}=$ phytic phosphorus/inorganic phosphorus; $\mathrm{YP}=$ yellow pigment; $\mathrm{WSPH}=$ water soluble phenolics; $\mathrm{PSH}=$ free protein sulfhydryl groups 
In comparison to our results, higher mean PA contents for Indian bread and durum wheat of $23.9 \mathrm{mg} \mathrm{g}^{-1}$ and 19.3 $\mathrm{mg} \mathrm{g}^{-1}$, respectively, were reported by Yenagi and Basarkar (2008). Khan et al. (2007) found the PA range to vary from 9.8 to $21.7 \mathrm{mg} \mathrm{g}^{-1}$ for 66 mutants and cultivars of bread wheat, with the mean value of $15 \mathrm{mg} \mathrm{g}^{-1}$. The $P_{i}$ content was in the range of $0.335-0.562$ and $0.312-0.499 \mathrm{mg} \mathrm{g}^{-1}$ for bread wheat genotypes and durum wheat genotypes, respectively (Table 1$)$. The highest $P_{i}$ level $\left(0.562 \mathrm{mg} \mathrm{g}^{-1}\right)$ among bread wheat genotypes was found in Abe. Varano and 37ED. 7817 ( 0.499 and $0.476 \mathrm{mg} \mathrm{g}^{-1}$, respectively) had the highest $P_{i}$ content among durum wheat genotypes. According to Ficco et al. (2009) 84 durum wheat cultivars grown in the multi-environment trial showed different $P_{1}$ means based on the classification to the three groups of cultivars: old $\left(0.62 \mathrm{mg} \mathrm{g}^{-1}\right)$, modern $\left(0.59 \mathrm{mg} \mathrm{g}^{-1}\right)$ and advanced $\left(0.55 \mathrm{mg} \mathrm{g}^{-1}\right)$. The mean values of PA and $P_{i}$ were higher in bread wheat assortment ( 16.05 and $0.427 \mathrm{mg}$ $\mathrm{g}^{-1}$, respectively) in comparison to durum wheat $\left(15.91\right.$ and $\left.0.418 \mathrm{mg} \mathrm{g}^{-1}\right)$, but not significantly $(p<0.05)$ as shown by $t$-test (Table 1). The high broad-sense heritability of the phytic acid content of $93.4 \%$ and $86 \%$ were observed in bread wheat by Gupta et al. (2015) and Ahmad et al. (2013), respectively. The Ipa mutant Js-12-LPA of Triticum aestivum produced seed in which PA phosphorus represented $48.2 \%$ of seed total $P$, in contrast to $74.7 \%$ of seed total P of nonmutant control, Js-12-WT (Guttieri et al. 2004). The seed P, was increased from 9.1\% in Js-12-WT to $50.1 \%$ in Js-12-LPA. Unfortunately, these Ipa mutations have pleiotropic effects and adversely affected the yield in wheat by reducing it by about 25\% while the kernel size was smaller by approximately $3 \mathrm{mg}$ (Guttieri et al. 2006, Zhao et al. 2008). The strategy of developing Ipa crops using mutation breeding may seriously obstruct seed germination and plant performance, which will eventually affect yields (Shahzad et al. 2014). Vella (2007) discovered major QTLs responsible for the phytic acid level in Triticum aestivum located on chromosomes 7B, $1 A S$ and $1 A L$, and also minor QTLs located on chromosomes 3B, 6A, 2B, 1D, 1B and 7D. Genetic engineering approaches to reduce PA in maize and soya bean showed the possibility to produce GMO cereal with low PA and with no effects on agronomic performance by tissue-specific silencing the expression of transporters involved in the biosynthesis of PA (Shi et al. 2007). The $P_{p} / P_{i}$ ratio is significant because it shows bioavailability of phosphorus in humans and nonruminant animals, ranging from 8.96 to 13.66 for bread wheat assortment and from 9.57 to 14.65 for durum wheat (Table 1). The lowest $P_{p} / P_{i}$ level among bread wheat genotypes was in $A$ be (8.96). Also the lowest $P_{p} / P_{i}$ was found in 37ED. 7817 and Varano (9.57 and 9.64, respectively) for durum wheat assortment. $A P_{p} / P_{i}$ mean value was found to be higher in durum wheat genotypes (11.18) than in bread wheat genotypes (10.99), but it was not significantly $(p<0.05)$ different.

\section{Variability of YP}

The YP content varied from 3.14 to $5.29 \mu \mathrm{g} \beta C \mathrm{~g}^{-1}$ in bread wheat genotypes and from 3.05-5.32 $\mathrm{mg} \mathrm{g}^{-1}$ in durum wheat genotypes (Table 1). The highest YP contents (5.29 and $5.32 \mu \mathrm{g} \beta C E \mathrm{~g}^{-1}$ ) were recorded in Apache (bread wheat genotype) and 37ED. 7922 (durum wheat genotypes), respectively. As expected, a higher mean YP value was ascertained in durum in comparison to bread wheat ( $3.87 \mathrm{vs} .4 .24 \mu \mathrm{g} \beta C E \mathrm{~g}^{-1}$ ), but the difference between them was not significant $(p<0.05)$. Solar radiation and a precipitation sum were found to be essential climatic factors influencing the YP content in bread and durum wheat (Clarke et al. 2006, Lukow et al. 2012, Branković et al. 2015). Petrova (2007) reported the YP mean value of $6.5 \mathrm{\mu g} \mathrm{g}^{-1}$ for the Bulgarian durum wheat assortment, comprising of 589 durum wheat breeding lines and released varieties, tested over the 1986-2005 period. The high YP content (above $8.5 \mathrm{ppm}$ ) is the requirement for pasta processing industry worldwide (Abdalla et al. 1995). However, Blanco et al. (2011) reported YP values of up to $10.96 \mu \mathrm{g} \mathrm{g}^{-1}$ for the segregant population of durum wheat evaluated at the two environments. According to Geleta and Grausgruber (2013) the YP content was in the range of 2.0-4.8 $\mu \mathrm{g} \mathrm{g}^{-1}$ for bread wheat and 2.6-5.5 $\mathrm{g} \mathrm{g} \mathrm{g}^{-1}$ durum wheat. Lower values than ours for the YP content for genotypes of bread and durum wheat were reported by other authors (Panfili et al. 2004, Borrelli et al. 2008, Hadži-Tašković Šukalović et al. 2013), whereas higher values were also documented (Ram and Mishra 2008, Sakin et al. 2011, Mohammed et al. 2012). The location of QTLs for the YP content was proved to be at the durum wheat chromosomes 6B and 7B (Pozniak et al. 2007), 3B, 5B and 1A (Patil et al. 2008) and 7A (Singh et al. 2009). The QTLs for the YP content in bread wheat are located at chromosomes 3A (Parker et al. 1998), 7A (Singh et al. 2009) and 7B (Pozniak et al. 2007). The content of $\beta$-carotene increase was achieved by genetic transformation of rice ("golden rice") via integration of the phytoene synthase (Psy) gene from daffodil (Narcissus pseudonarcissus L.) and the carotene desaturase (Crtl) gene from the bacterium Pantoea ananatis (previously known as Erwinia uredovora) (Ye et al. 2000).

\section{Variability of WSPH}

The WSPH content ranged from 728.02 to $1347.39 \mu \mathrm{g} \mathrm{FAE} \mathrm{g}^{-1}$ for bread wheat genotypes and from 884.10 to 1124.21 $\mathrm{mg} \mathrm{g}^{-1}$ for durum wheat genotypes (Table 1). Among bread wheat genotypes cultivar Stephens expressed the highest WSPH content (1347.39 $\left.\mathrm{g} \mathrm{FAE} \mathrm{g}^{-1}\right)$. The highest WSPH content among durum wheat genotypes was found in ZP 120/I and 37ED./07 7849 (1124.21 and 1113.44 $\mu$ g FAE g-1 , respectively). The WSPH mean value was higher in bread $\left(1023.26 \mu \mathrm{g} \mathrm{FAE} \mathrm{g}^{-1}\right)$ than in durum wheat $\left(998.91 \mu \mathrm{g} \mathrm{FAE} \mathrm{g}^{-1}\right)$, but not significantly different $(p<0.05)$. According to Žilić et al. (2011) the total phenolics content for bread wheat was in the range of 1.02-1.60 mg CE g ${ }^{-1}$ 
with the mean value of $1.30 \mathrm{mg} \mathrm{CE} \mathrm{g}^{-1}$, and for durum wheat 1.52-1.65 mg CE g-1 with the mean value of $1.58 \mathrm{mg}$ $\mathrm{CE} \mathrm{g}^{-1}$ with the similar CV as in our study for both species. Žilić et al. (2013) documented 1.19-fold higher total phenolic compounds in durum wheat samples than in bread wheat samples and the average value of $1.20 \mathrm{CE} \mathrm{mg} \mathrm{g}^{-1}$ (ranged from 0.99 to 1.60) and $1.43 \mathrm{CE} \mathrm{mg} \mathrm{g}^{-1}$ (ranged from 1.27 to 1.65) in bread and durum wheat, respectively. A lower total phenolics content than reported in our investigation was found by Dinelli et al. (2009), whereas higher values were also reported (Abdel-Aal and Rabalski 2008, Hadži-Tašković Šukalović et al. 2013, Pasqualone et al. 2014). Vences et al. (1982) studying Triticum aestivum L. found QTLs for the phenolic compounds to be located on the chromosomes or chromosome arms $1 \mathrm{~B}, 2 \mathrm{BL}, 3 \mathrm{BL}, 5 \mathrm{~A}, 6 \mathrm{AL}, 7 \mathrm{~B}$ and $7 \mathrm{DS}$.

\section{Variability of PSH}

The PSH content varied from 78.95 to $102.23 \mathrm{nmol} \mathrm{g}^{-1}$ in bread wheat genotypes and from 49.20-114.58nmol g-1 in durum wheat genotypes (Table 1). The highest PSH content recorded in bread wheat genotypes (Tecumseh), i.e. durum wheat genotypes (ZP 120/I) amounted to 102.23, i.e. $114.58 \mathrm{nmol} \mathrm{g}^{-1}$, respectively. The mean value of PSH was higher in the durum assortment $\left(93.15 \mathrm{nmol} \mathrm{g}^{-1}\right)$ in comparison to bread wheat $\left(89.61 \mathrm{nmol} \mathrm{g}^{-1}\right)$ although not significantly $(p<0.05)$. Purna (2010) obtained lower values for bread wheat samples ranging from 8.17 to 34.91 $\mathrm{nmol} \mathrm{g}^{-1}$. According to Antes and Wieser (2000) the highest PSH content found in commercial wheat flour was in the SDS soluble glutenins, then water soluble proteins and then in globulins. Quantitative trait loci (QTLs) controlling amino acid cysteine containing a free sulfhydril group in Triticum aestivum L. was reported to be on chromosomes 2 D and 3 D (Jiang et al. 2013).

\section{Correlation analysis}

Correlations between PA, antioxidants and agronomic traits of bread and durum wheat, are of particular importance for breeding varieties for functional food purpose, but their relationships remain to a large extent unexplored. Highly significant, positive, medium high to high, consistent correlations across four environments were observed for PA and $P_{i}$ in bread wheat (Supplementary Table 3). Israel et al. (2006) also detected a positive correlation between $\mathrm{PA}$ and $\mathrm{P}_{\mathrm{i}}(0.72, p<0.01)$ among wild-type soya bean lines of the maturity group $\mathrm{V}$, which was in our reported interval. Significant, positive, medium high to high, consistent correlations across two environments were found between PSH and YP in durum wheat (Supplementary Table 4). Antioxidants in wheat and among them YP and PSH are concentrated mostly in the aleurone layer of bran with some in the pericarp, nucellar envelope, and germ (Moore et al. 2005). The same climatic factors as increased precipitation in later phases of vegetation season and also less solar radiation contribute to the higher levels of PSH and YP in durum wheat as reported by Branković et al. (2015). Significant, negative, medium correlations were revealed for PA and YP in two environments, $\mathrm{P}_{\mathrm{p}} / \mathrm{P}_{\mathrm{i}}$ and WSPH in single environment in bread wheat (Supplementary Table 3), and also for PA and WSPH in two environments in durum wheat (Supplementary Table 4). As reported by Branković et al. (2015) genotype was the most important source of variation for YP, and GEl was for PA in bread wheat. At the two environments RS11 and RS12 the correlation between YP and PA was negative, probably due to inverse effects of the highest observed sunshine hours duration and the lowest precipitations during May and June at this location in both growing seasons in comparison to the other two locations. The same climatic factors probably influenced $P_{i}$ and WSPH, but in the same direction leading to negative correlation between $P_{p} / P_{i}$ and WSPH, as it was shown previously by Branković et al. (2015). The negative correlations observed between PA and WSPH can be explained with the effects of decreased precipitation and sunshine hours at the ZP11 and ZP12 environments in comparison to the other environments, which contributed to the higher PA and smaller WSPH levels in durum wheat in these environments (Branković et al. 2015). It is of special interest to determine the relation between PA as antinutrient and WSPH because according to Dykes and Rooney (2007) this antioxidant contributes significantly to the total antioxidant wheat grain activity. Mladenović Drinić et al. (2009) reported a low to medium positive correlation between PA and WSPH, as well as between PA and PSH in maize. Liu et al. (2006) found a significant correlation between PA and $P_{i}(r=0.43, p<0.01)$. The pairs of significantly positively correlated agronomic and chemical characteristics with a medium correlation were: PH and PA in bread wheat in two environments (Supplementary Table 3) and GW and PSH in durum wheat in two environments (Supplementary Table 4). The pairs of significantly and highly significantly, negatively medium to medium high correlated agronomic and chemical characteristics in two different environments were: GL and PA, SL and PA, SL and $P_{i}$ in bread wheat (Supplementary Table 3); and TGW and YP, GT and YP, GW and YP for durum wheat (Supplementary Table 4). Ficco et al. (2009) using the principal component analysis and the Pearson's correlation found a negative association of $\mathrm{P}_{\mathrm{i}}$ and TGW $(-0.31 p<0.01)$ 
and of $P_{i}$ and YLD $(-0.27 p<0.05)$ in durum wheat, while similar findings were confirmed by other studies (Monasterio and Graham 2000, Liu et al. 2006). According to Lee at al. (2014) phytase activity affecting the PA content in wheat appeared to be determined by the grain length to width ratio. The shape and size of wheat grains affect the test weight, protein content, the activity of hydrolytic enzymes, which affect the baking quality and the quality of the final product (Evers 2000). Clarke et al. (2006) found a variable, weak, and a negative correlation between the kernel weight and YP $(-0.45, p<0.05)$ in durum wheat while in our study the TGW and YP correlation was stronger $(-0.614, p<0.05$ and $-0.666, p<0.05)$.

\section{Genotype by trait analyses of interrelationship between chemical and agronomic characteristics from multi-environment trial}

Based on the GT analysis for the six environments used in our investigation for bread and durum wheat (Figs. 1 and 2 ), the possibilities were deduced that could be used for breeding and improving the properties of PA and antioxidants content in wheat. The favourable direction is reducing PA and increasing the antioxidant content of bread and durum wheat genotypes. A GT biplot can help comprehend the relationships among breeding objectives and identify traits that can be used in indirect selection for another trait (Yan and Tinker 2006). We took into account associations of characteristics only if they were recorded in four and more test-environments studied. A positive association was determined between WSPH and YP and PA and $P_{i}$ in bread wheat and durum wheat (Figs. 1 and 2), while correlation coefficients confirmed this only for durum wheat (Supplementary Table 4). PA and PSH and $\mathrm{P}_{\mathrm{i}}$ and PSH in bread wheat were positively associated (Fig. 1). Also, positive associations were found for WSPH and PSH and WSPH and $\mathrm{P}_{i}$ in durum wheat (Fig. 2), which is in accordance with the observed correlation coefficients (Supplementary Table 4). A negative association was determined between PA and YP and PA and WSPH in bread wheat (Fig. 1), and also between PA and each of examined antioxidants (YP, WSPH, PSH) in durum wheat (Fig. 2). YP and PSH were negatively associated in bread wheat (Fig. 1) and positively in durum wheat (Fig. 2), which corresponded with the observed correlation coefficients for durum wheat (Supplementary Table 4). The relation between PSH and WSPH was less pronounced, while a positive relationship existed in three environments, but also a negative one existed in three environments for bread wheat (Fig. 1). YLD had a negative association with each of the examined antioxidants PSH, WSPH (confirmed also by the correlation coefficient) (Supplementary Table 3), YP in bread wheat (Fig. 1). YLD showed a negative association with YP and PA (Fig. 2) (confirmed also with the correlation coefficient) (Supplementary Table 4) in durum wheat. YLD was positively associated with WSPH and PSH in durum wheat (Fig. 2). Effects of climatic factors associated to drought stress and high temperature during grain filling may lead to high phenolic content (Menga et al. 2010) and PSH content (Branković et al. 2014), but to decreased yield in bread wheat, whereas durum wheat is capable of enduring these conditions without significant yield reductions. In bread wheat, the association between YLD and PA was not consistent and was positive in three environments (Fig. 1), but also negative in three environments. The correlation observed between these traits was significant but negative. Such correlation indicates that the development of high-yielding genotypes with a lower PA should be an attainable goal in maize according to Mladenović Drinić et al. (2009).

SL was positively associated with YP in bread and durum wheat (Figs. 1 and 2) what was confirmed with the correlation coefficient for durum wheat (Supplementary Table 4), and also with WSPH and $\mathrm{P}_{\mathrm{i}}$ (Fig. 2), but only in durum wheat. PH had a positive relation with PSH and PA (Fig. 1) (also confirmed by the correlation coefficients, Supplementary Table 3), in bread wheat, and with each of the examined antioxidants YP, WSPH (also confirmed by the correlation coefficients, Supplementary Table 4) and PSH (Fig. 2) (also confirmed by the correlation coefficient, Supplementary Table 4) in durum wheat. PTC was positively associated with PA (Fig. 1) in bread wheat and with WSPH and PSH (Fig. 2) in durum wheat. GL showed a positive association with $\mathrm{P}_{1}$ and with each of the examined antioxidants PSH, YP and WSPH (Fig. 2) in durum wheat. Geleta and Grausgruber (2013) reported a negative association of YP and TGW based on the GT analysis for both, bread and durum wheat. GNS was positively associated with YP and with PSH in durum wheat (Fig. 2). GW, GT, and TGW, each, were positively associated with PSH (Fig. 2) in durum wheat, but the correlation coefficient confirmed only the association between TGW and PSH (Supplementary Table 4). GW and PA and also GT and PA (Fig. 2) were positively associated in durum wheat. In contrast to conventional breeding, biofortification aims to positively affect human micronutrient status, merging breeding with nutrition and socioeconomics research, to improve health characteristics (Cakmak et al. 2010) while maintaining favourable agronomic characteristics. 

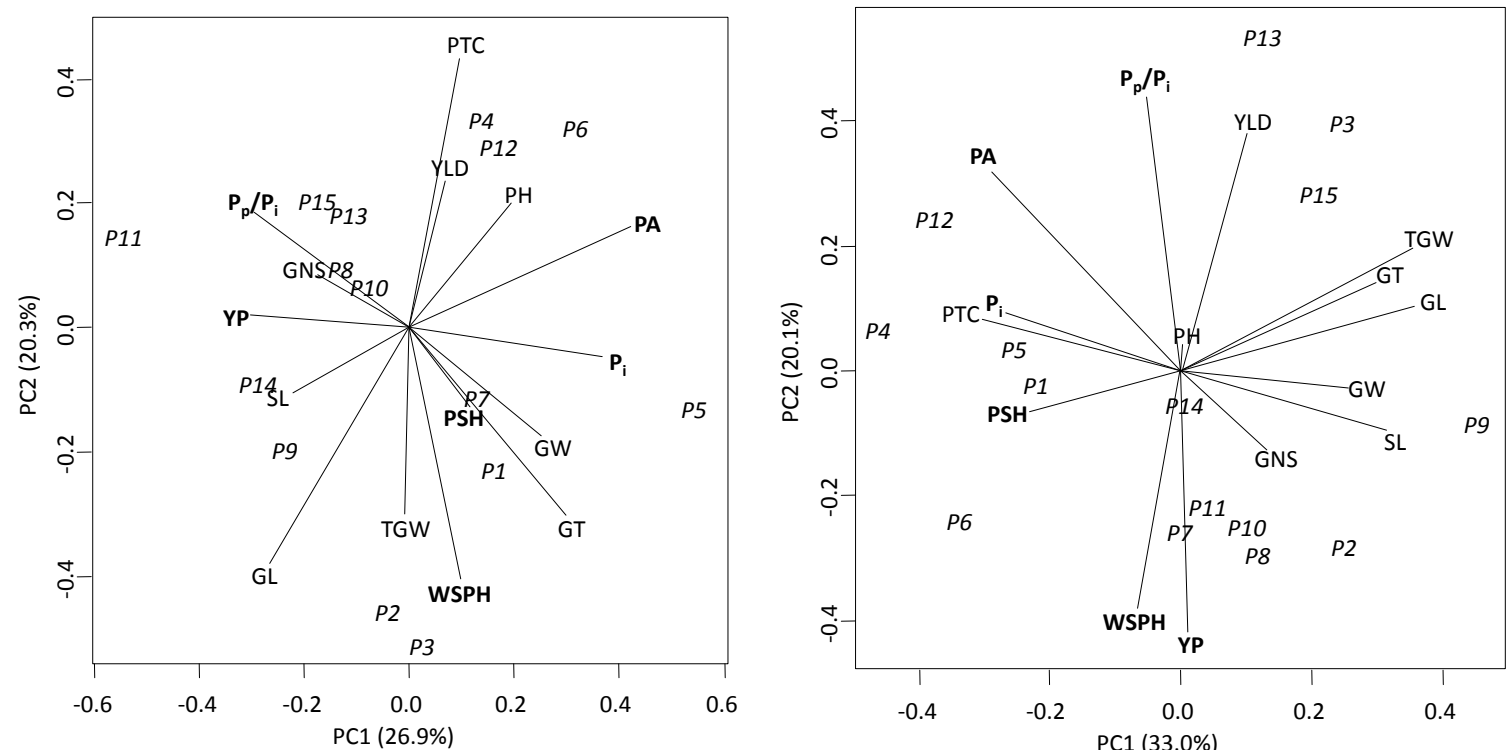

(a)
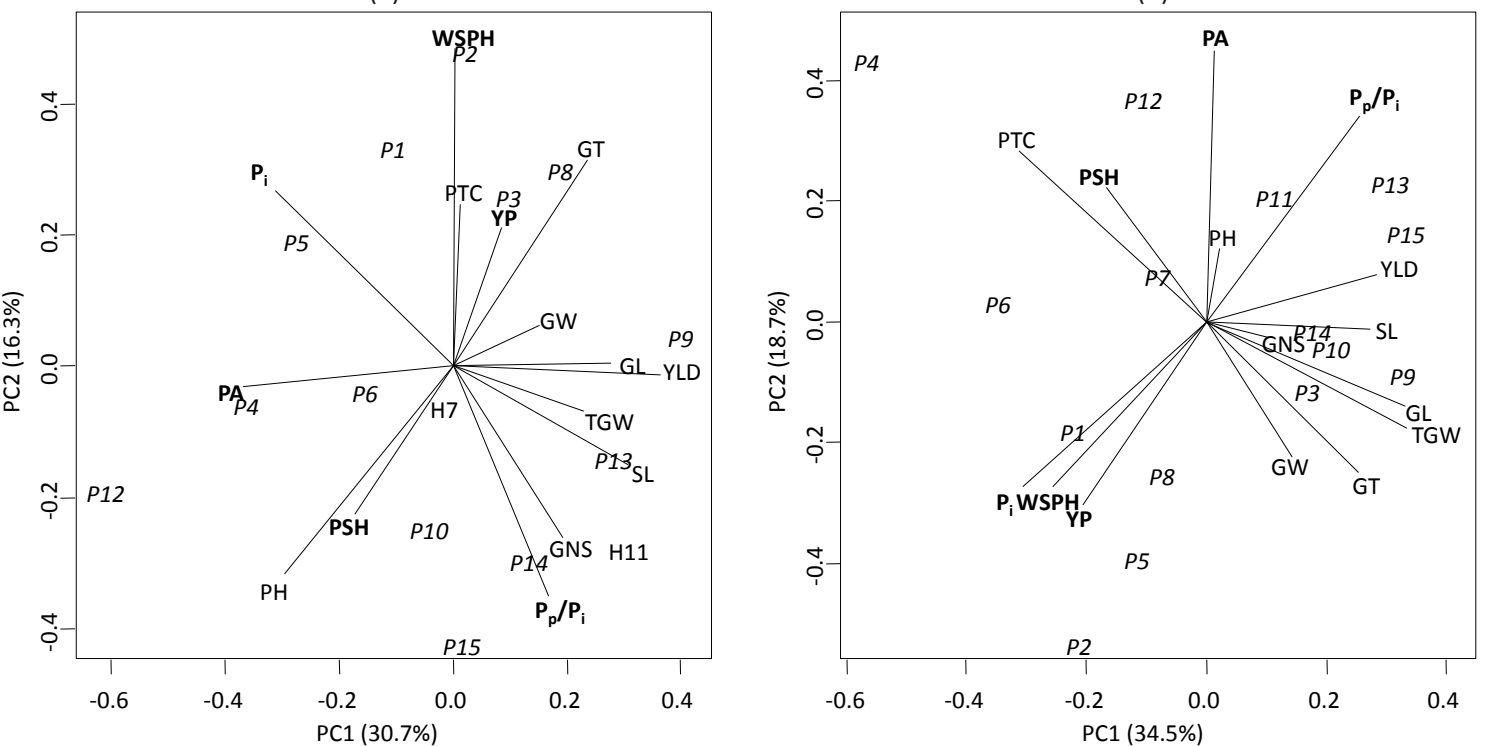

(c)

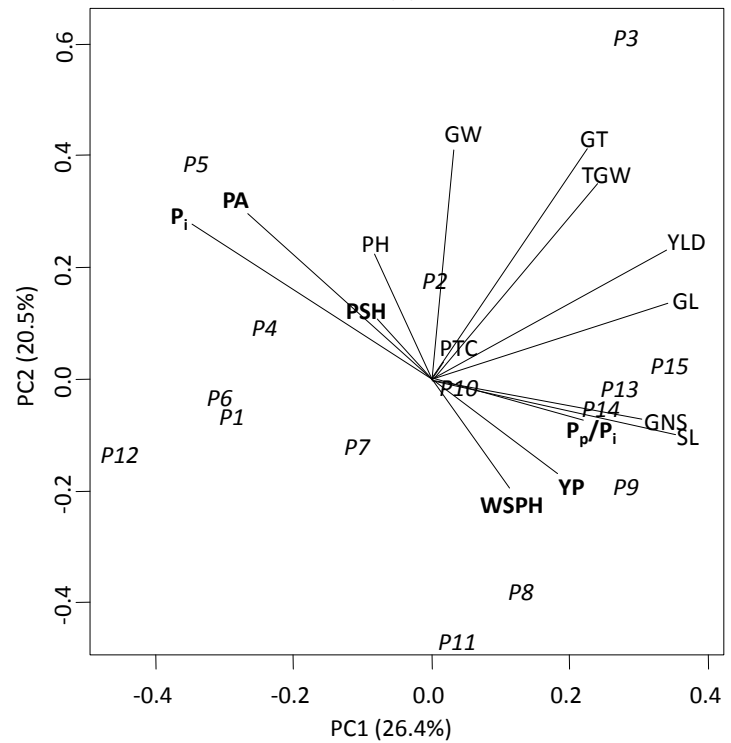

(e)

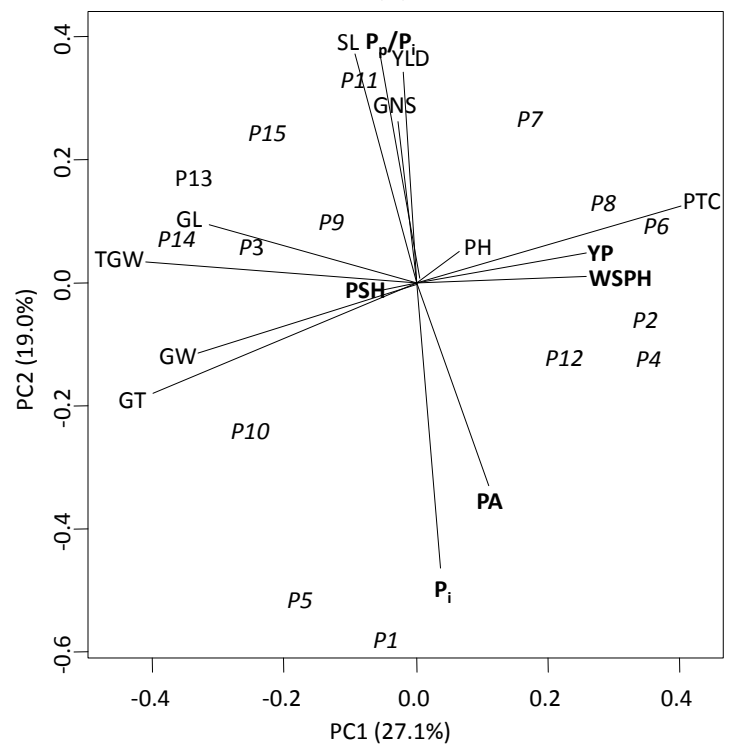

(f)

Fig. 1. Genotype by trait (GT) biplot of 15 bread wheat genotypes ( $P 1-P 15)$ by nine agronomic and six chemical characteristics measured across six environments (Rimski Šančevi for 2010-2011 (a) and 2011-2012 (b) vegetation season, Zemun Polje for 20102011 (c) and 2011-2012 (d) vegetation season and Padinska Skela for 2010-2011 (e) and 2011-2012 (f) vegetation season). YLD = grain yield; TGW = thousand grain weight; $\mathrm{PH}=$ plant height; $\mathrm{SL}=$ spike length; $\mathrm{GNS}$ = grain number per spike; $\mathrm{GL}=$ grain length; $\mathrm{GW}$ = grain width; $\mathrm{GT}=$ grain thickness; $\mathrm{PTC}=$ productive tillering coefficient; $\mathrm{PA}=$ phytic acid; $\mathrm{P}_{\mathrm{i}}=$ inorganic phosphorus; $\mathrm{P}_{\mathrm{p}} / \mathrm{P}_{\mathrm{i}}=$ phytic phosphorus/inorganic phosphorus; YP = yellow pigment; WSPH = water soluble phenolics; PSH = free protein sulfhydryl groups 


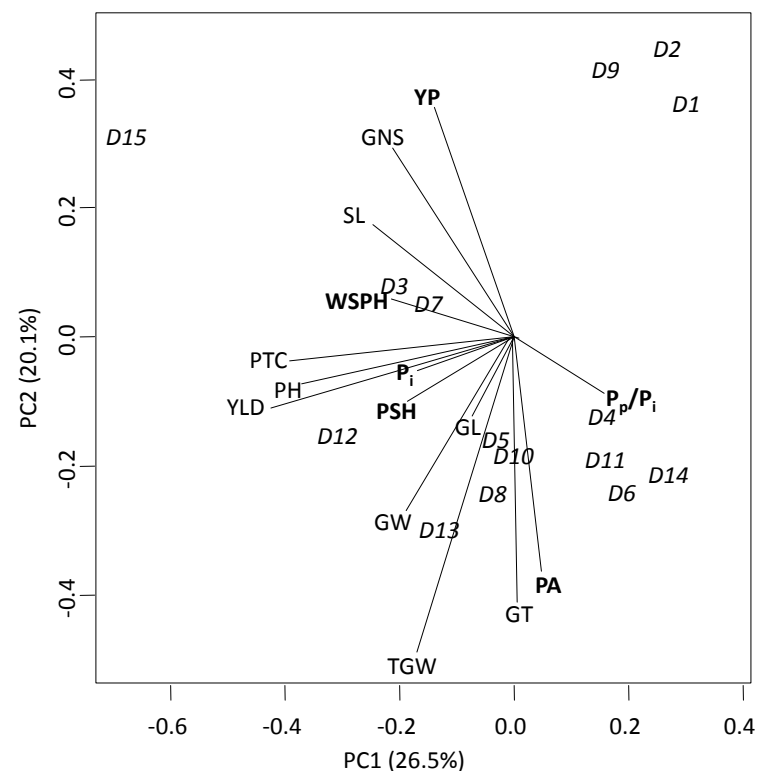

(a)

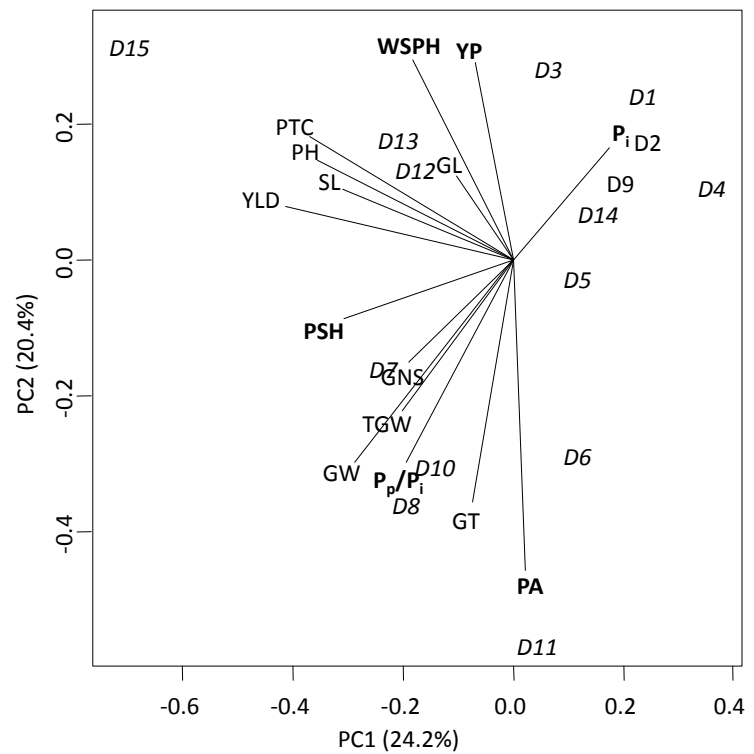

(c)

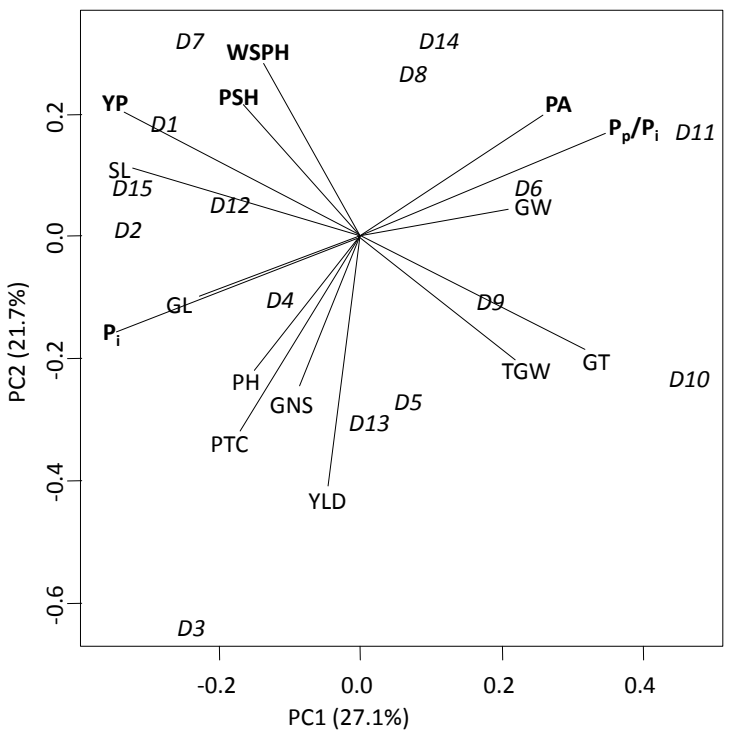

(e)

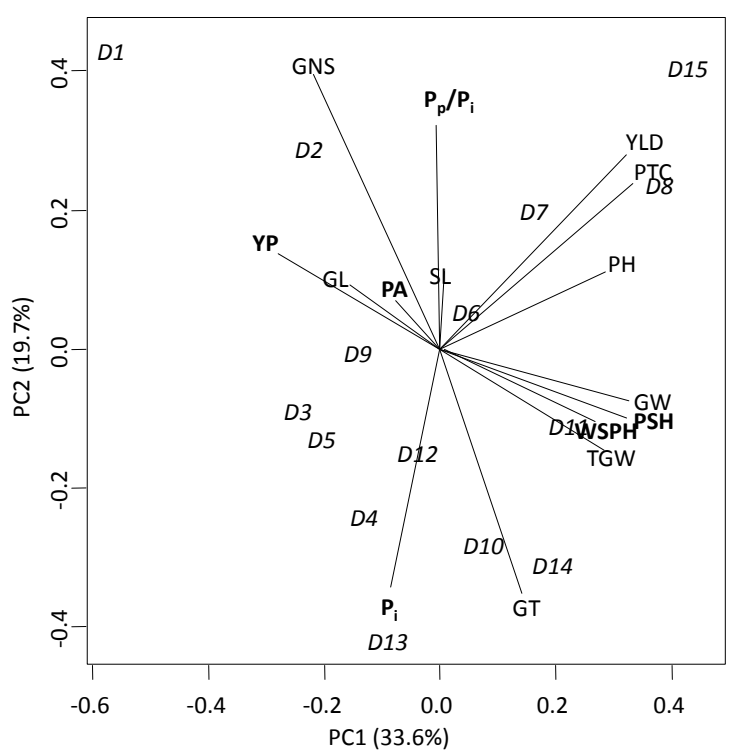

(b)

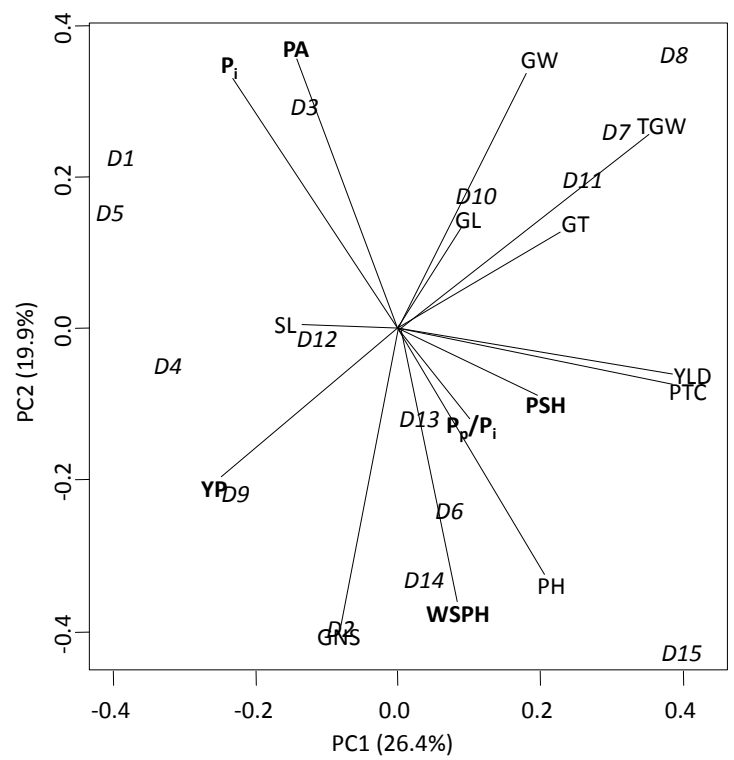

(d)

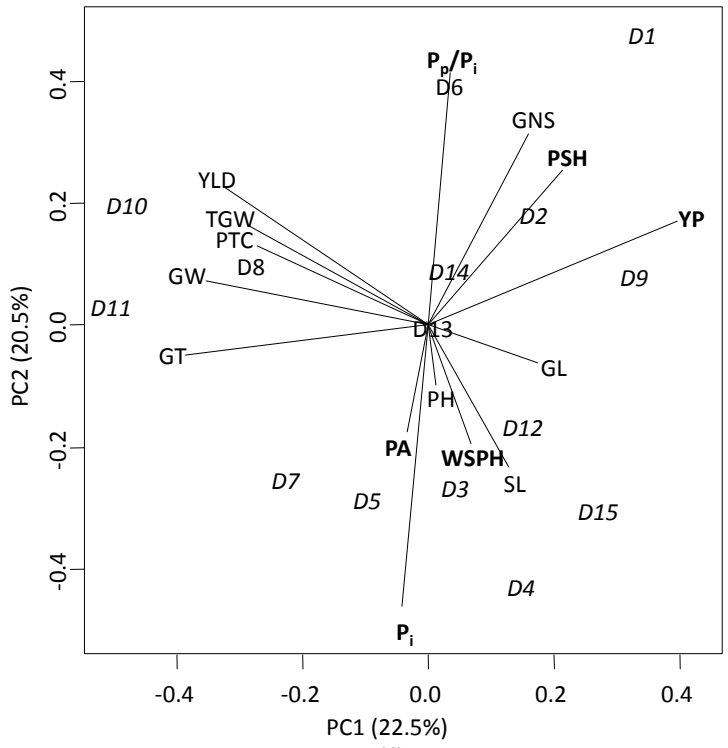

(f)

Fig. 2. Genotype by trait (GT) biplot of 15 durum wheat genotypes (D1-D15) by nine agronomic and six chemical characteristics, measured across six environments (Rimski Šančevi for 2010-2011 (a) and 2011-2012 (b) vegetation season, Zemun Polje for 2010-2011 (c) and 2011-2012 (d) vegetation season and Padinska Skela for 2010-2011 (e) and 2011-2012 (f) vegetation season). YLD = grain yield; TGW = thousand grain weight; $\mathrm{PH}=$ plant height; $\mathrm{SL}=$ spike length; $\mathrm{GNS}=$ grain number per spike; $\mathrm{GL}=$ grain length; $\mathrm{GW}=$ grain width; $\mathrm{GT}=$ grain thickness; PTC = productive tillering coefficient; $P A=$ phytic acid; $P_{i}=$ inorganic phosphorus; $P_{p} / P_{i}=$ phytic phosphorus/inorganic phosphorus; YP = yellow pigment; WSPH = water soluble phenolics; $P S H=$ free protein sulfhydryl groups 


\section{Conclusions}

Associations obtained in the multi-environment trail showed possibility for simultaneous breeding for high WSPH and YP in bread and durum wheat, YP and PSH, and WSPH and PSH in durum wheat. The negative association was found between PA and YP, PA and WSPH in bread wheat, and also between PA and each of examined antioxidants in durum wheat, which can lead to the development of cultivars with better bioavailability of micronutrient and higher antioxidants contents for functional food purposes. The negative association of YLD and each of examined antioxidants unfortunately indicates difficulties for breeders to select at the same time for high YLD and high antioxidants levels in bread wheat, although the relation with PA was not consistent across environments. Suitable agronomic traits for indirect selection for PA proved to be PH and PTC in bread wheat, whereas GW and GT in durum wheat. On the contrary, different genetic background of tetraploid durum wheat led to the positive associations of YLD with WSPH, and PSH, and the negative one with PA, indicating ability for deriving productive, nutritious and health beneficial durum wheat cultivars at the same time.

\section{Acknowledgement}

Authors acknowledge the financial support by the Ministry of Education, Science and Technological Development of the Republic Serbia given to this study carried within the Project TR 31092.

\section{References}

Abdalla, O.S., Peña, R.J., Autrique, J.E. \& Nachit, M. 1995. Durum wheat breeding and quality improvement at CIMMYT Mexico. In: Di Fonzo, N., Kaan, F. \& Nachit, M. (eds.). Durum wheat quality in the Mediterranean region. Zaragoza, Spain: CIHEAM. p. 133-141.

Abdel-Aal, E.S.M. \& Rabalski, I. 2008. Bioactive compounds and their antioxidant capacity in selected primitive and modern wheat species. Open Agriculture Journal 2: 7-14.

Adams, J.D.Jr., Klaidman, L.K., Odunze, I.N., Shen, H.C. \& Miller, C.A. 1991. Alzheimer's and Parkinson's disease. Brain levels of glutathione, glutathione disulfide, and vitamin E. Molecular and Chemical Neuropathology 14: 213-226.

Ahmad, I., Mohammad, F., Zeb, A., Noorka, I., Farhatullah \& Jadoon, S. 2013. Determination and inheritance of phytic acid as marker in diverse genetic group of bread wheat. American Journal of Molecular Biology 3: 158-164.

American Association of Cereal Chemists, 1995. Pigments. Methods 14-50. AACC Methods $9^{\text {th }}$ ed. St. Paul, Minnesota, USA: American Association of Cereal Chemistry.

Antes, S. \& Wieser, H. 2000. Quantitative determination and localisation of thiol groups in wheat flour. In: Shewry, P.R. \& Tatham, A.S. (eds.) Wheat gluten. Bristol, UK: The Royal Society of Chemistry. p. 211-214.

Barac, M.B., Jovanovic, S.T., Stanojevic, S.P. \& Pesic, M.B. 2006. Effect of limited hydrolysis on traditional soy protein concentrate. Sensors 6: 1087-1101.

Blanco, A., Colasuonno, P., Gadaleta, A., Mangini, G., Schiavulli, A., Simeone, R., Digesù, A.M., de Vita, P., Mastrangelo, A.M. \& Cattivelli, L. 2011. Quantitative trait loci for yellow pigment concentration and individual carotenoid compounds in durum wheat. Journal of Cereal Science 54: 255-264.

Borrelli, G.M., de Leonardis, A.M., Platani, C. \& Troccoli, A. 2008. Distribution along durum wheat kernel of the components involved in semolina colour. Journal of Cereal Science 48: 494-502.

Branković, G. 2014. Variability and stability of wheat for phytic acid and antioxidants content. PhD thesis. Belgrade, Serbia: University of Belgrade, Faculty of Agriculture. 242 p.

Branković, G., Dragičević, V., Dodig, D., Zorić, M., Knežević, D., Žilić, S., Denčić, S. \& Šurlan, G. 2015. Genotype x environment interaction for antioxidants and phytic acid contents in bread and durum wheat as influenced by climate. Chilean Journal of Agricultural Research 75: 139-146.

Cakmak, I., Pfeiffer, W.H. \& McClafferty B. 2010. Biofortification of durum wheat with zinc and iron. Cereal Chemistry 87: 10-20.

Chernikova, T., Robinson, J.M., Lee, E.H. \& Mulchi, C.L. 2000. Ozone tolerance and antioxidant enzyme activity in soybean cultivars. Photosynthesis Research 64: 15-26.

Clarke, F.R., Clarke, J.M., McCaig, T.N., Knox, R.E. \& dePauw, R.M. 2006. Inheritance of yellow pigment concentration in seven durum wheat crosses. Canadian Journal of Plant Science 86: 133-141.

Cuttriss, A.J., Mimica, J.L., Howitt, C.A. \& Pogson, B.J. 2006. Carotenoids. In: Wise, R.R. \& Hoober, J.K. (eds.). The structure and function of plastids. Dordrecht, Netherlands: Springer. p. 315-334.

de Kok, L.J., de Kan, P.J.L., Tánczos, O.G. \& Kuiper, P.J.C. 1981. Sulphate induced accumulation of glutathione and frost-tolerance of spinach leaf tissue. Physiologia Plantarum 53: 435-438.

Dinelli, G., Carretero, A.S., di Silvestro, R., Marotti, I., Fu, S., Benedettelli, S., Ghiselli, L. \& Gutiérrez, A.F. 2009. Determination of phenolic compounds in modern and old varieties of durum wheat using liquid chromatography coupled with time-of-flight mass spectrometry. Journal of Chromatography A 1216: 7229-7240.

Dragičević, V., Sredojević, S., Perić, V., Nišavić, A. \& Srebrić, M. 2011. Validation study of a rapid colorimetric method for the determination of phytic acid and inorganic phosphorus from seeds. Acta Periodica Technologica 42: 11-21.

Drankhan, K., Carter, J., Ron, M., Carol, K., Frank, P., Yemen, L., Thomas, W., Neil, S. \& Dolores, T.J. 2003. Antitumor activity of wheats with high orthophenolic content. Nutrition and Cancer 47: 188-194. 
G. Branković et al. (2015) 24: 183-194

Dykes, L. \& Rooney, L.W. 2007. Phenolic compounds in cereal grains and their health benefits. Cereal Foods World 52: 105-111. Evers, A.D. 2000. Grain size and morphology: implications for quality. In: Schofield, D. (ed.). Wheat structure, biochemistry and functionality. London, UK: Royal Society of Chemistry. p. 19-24.

Ficco, D.B.M., Riefolo, C., Nicastro, G., de Simone, V., di Gesú, A.M., Beleggia, R., Platani, C., Cattivelli, L. \& de Vita, P. 2009. Phytate and mineral elements concentration in a collection of Italian durum wheat cultivars. Field Crops Research 111: $235-242$.

Geleta, N. \& Grausgruber, H. 2013. Morphological and quality traits variation in tetraploid (Triticum turgidum L.) and hexaploid (Triticum aestivum L.) wheat accessions from Ethiopia. Agricultural Science Research Journals 3: 229-236.

Graham, R.D. \& Rosser, J.M. 2000. Carotenoids in staple foods: Their potential to improve human nutrition. Food and Nutrition Bulletin 21: 404-409.

Gupta, R.K., Gangoliya, S.S. \& Singh N.K. 2015. Screening and characterization of wheat germplasms for phytic acid and iron content. Journal of Agricultural Science and Technology 17: 747-756.

Guttieri, M.J., Bowen, D., Dorsch, J.A., Raboy, V. \& Souza, E. 2004. Identification and characterization of low phytic acid wheat. Crop Science 44: 418-424.

Guttieri, M.J., Peterson, K.M. \& Souza, E.J. 2006. Agronomic performance of low phytic acid wheat. Crop Science 46: $2623-2629$.

Hadži-Tašković Šukalović, V., Dodig, D., Žilić, S., Basić, Z., Kandić, V., Delić, N. \& Miritescu, M. 2013. Genotypic and environmental variation of bread and durum wheat proteins and antioxidant compounds. Romanian Agricultural Research 30: 125-134.

Israel, D.W., Kwanynen, P. \& Burton, J.W. 2006. Genetic variability for phytic acid phosphorus and inorganic phosphorus in seeds of soybeans in maturity groups V, VI, and VII. Crop Science 46: 67-71.

IUSS-World Reference Base for Soil Resources, 2006. A framework for international classification, correlation and communication (World Soil Resources Reports). 2d ed. Rome, Italy: Food and Agriculture Organization of the United Nations. 128 p.

Jiang, X., Deng, Z., Ru, Z., Wu, P. \& Tian, J. 2013. Quantitative trait loci controlling amino acid contents in wheat (Triticum aestivum L.). Australian Journal of Crop Science 7: 820-829.

Khan, A.J., Ali, A., Azam, F.I. \& Zeb, A. 2007. Identification and isolation of low phytic acid wheat (Triticum aestivum L.) inbred lines / mutants. Pakistan Journal of Botany 39: 2051-2058.

Kim, H.Y., Kim, O.H. \& Sung, M.K. 2003. Effects of phenol-depleted and phenol-rich diets on blood markers of oxidative stress, and urinary excretion of quercetin and kaempferol in healthy volunteers. Journal of the American College of Nutrition 22: 217-223.

Kobrehel, K.S., Yee, B.C. \& Buchanan, B.B. 1991. Role of the NADP/thioredoxin system in the reduction of alpha-amylase and trypsin inhibitor proteins. The Journal of Biological Chemistry 266: 16135-16140.

Landrum, J.T. \& Bone, R.A. 2004. Dietery lutein and zeaxanthin: reducing the risk for macular degeneration. Agro Food Industry Hi Tech 15: 22-25.

Lee, H.H., Bong, C.F.J., Loh, S.P., Sarbini, S.R. \& Yiu, P.H. 2014. Genotypic, grain morphological and locality variation in rice phytate content and phytase activity. Emirates Journal of Food and Agriculture 26: 844-852.

Leustek, T., Martin, M.N., Bick, J.A. \& Davies, J.P. 2000. Pathways and regulation of sulfur metabolism revealed through molecular and genetic studies. Annual Review of Plant Physiology and Plant Molecular Biology 51: 141-165.

Liu, Z.H., Wang, H.Y., Wang, X.E., Zhang, G.P., Chen, P.D. \& Liu, D.J. 2006. Genotypic and spike positional difference in grain phytase activity, phytate, inorganic phosphorus, iron, and zinc contents in wheat (Triticum aestivum L.). Journal of Cereal Science 44: 212-219.

Lonnerdal, B. 2002. Phytic acid-trace element ( $\mathrm{Zn}, \mathrm{Cu}, \mathrm{Mn})$ interactions. International Journal of Food Science and Technology 37: 749-758.

Lott, J.N.A., Ockenden, I., Raboy, V. \& Batten, G.D. 2000. Phytic acid and phosphorus in crop seeds and fruits: a global estimate. Seed Science Research 10: 11-33.

Lukow, O., Suchy, J., Adams, K., Brown, D., de Pauw, R., Fox, S., Hatcher, D., Humphreys, G., McCaig, T. \& White, N. 2012. Effect of solar radiation, plant maturity and post-harvest treatment on the color and phenolic and carotenoid content in seed of red and white Canadian wheat. Journal of Cell and Plant Sciences 3: 1-13.

Meyer, A.S., Donovan, J.L., Pearson, D.A., Waterhouse, A.L. \& Frankel, E.N. 1998. Fruit hydroxycinnamic acids inhibit human low-density lipoprotein oxidation in vitro. Journal of Agricultural and Food Chemistry 46: 1783-1787.

Menga, V., Fares, C., Troccoli, A., Cattivelli, A. \& Baiano, A. 2010. Effects of genotype, location and baking on the phenolic content and some antioxidant properties of cereal species. International Journal of Food Science and Technology 45: 7-16.

Mladenović Drinić, S., Ristić, D., Sredojević, S., Dragičević, V., Micić-Ignjatović, D. \& Delić, N. 2009. Genetic variation of phytate and ionorganic phosphorus in maize population. Genetika-Belgrade 41: 107-115.

Mohammed, A., Geremew, B. \& Amsalu, A. 2012. Variation and associations of quality parameters in Ethiopian durum wheat (Triticum turgidum L. var. durum) genotypes. International Journal of Plant Breeding and Genetics 6: 17-31.

Monasterio, I. \& Graham, R.D. 2000. Breeding for trace minerals in wheat. Food and Nutrition Bulletin 21: 392-396.

Moore, J., Hao, Z., Zhou, K., Luther, M., Costa, J. \& Yu, L.L. 2005. Carotenoid, tocopherol, phenolic acid, and antioxidant properties of Maryland-grown soft wheat. Journal of Agricultural and Food Chemistry 53: 6649-6657.

Moore, J., Liu, J.G., Zhou, K.Q. \& Yu, L.L. 2006. Effects of genotype and environment on the antioxidant properties of hard winter wheat bran. Journal of Agricultural and Food Chemistry 54: 5313-5322.

Mpofu, A., Sapirstein, H.D. \& Beta, T. 2006. Genotype and environmental variation in phenolic content, phenolic acid composition, and antioxidant activity of hard spring wheat. Journal of Agricultural and Food Chemistry 54: 1265-1270.

Panfili, G., Fratianni, A. \& Irano, M. 2004. Improved normal-phase high-performance liquid chromatography procedure for the determination of carotenoids in cereals. Journal of Agricultural and Food Chemistry 52: 6373-6377. 
G. Branković et al. (2015) 24: 183-194

Parker, G.D., Chalmers, K.J., Rathjen, A.J. \& Langridge, P. 1998. Mapping loci associated with flour colour in wheat (Triticum aestivum L.). Theoretical and Applied Genetics 97: 238-245.

Pasqualone, A., Delvecchio, L.N., Mangini, G., Taranto, F. \& Blanco, A. 2014. Variability of total soluble phenolic compounds and antioxidant activity in a collection of tetraploid wheat. Agricultural and Food Science 23: 307-316.

Patil, R.M., Oak, M.D., Tamhankar, S.A., Sourdille, P. \& Rao, V.S 2008. Mapping and validation of a major QTL for yellow pigment content on 7AL in durum wheat (Triticum turgidum L. ssp. durum). Molecular Breeding 21: 485-496.

Prakash, M., Shetty, M.S., Tilak, P. \& Anwar, N. 2009. Total thiols: biomedical importance and their alteration in various disorders. Online Journal of Health and Allied Sciences 8: 2. http://www.ojhas.org/issue30/2009-2-2.htm. Cited 07 February 2015.

Peng, J.H., Sun, D. \& Nevo, E. 2011. Domestication evolution, genetics and genomics in wheat. Molecular Breeding 28: 281-301. Petrova, I. 2007. End-use quality of Bulgarian durum wheat. Bulgarian Journal of Agricultural Science 13: 161-169.

Pozniak, C.J., Knox, R.E., Clarke, F.R \& Clarke, J.M. 2007. Identification of QTL and association of a phytoene synthase gene with endosperm colour in durum wheat. Theoretical and Applied Genetics 14: 525-537.

Purna, S.K.G. 2010. Understanding and improving functionality of waxy wheat flours. PhD thesis. Manhattan, Kansas, USA: Kansas State University. $171 \mathrm{p}$.

Raboy, V. 2001. Seeds for a better future: "low phytate" grains help to overcome malnutrition and reduce pollution. Trends in Plant Science 6: 458-462.

R Development Core Team, 2013. R: A Language and environment for statistical computing: $R$ foundation for statistical computing. 3rd ed. Vienna, Austria: R Foundation for Statistical Computing. 3551 p.

Ram, S. \& Mishra, B. 2008. Biochemical basis and molecular genetics of processing and nutritional quality traits of wheat. Journal of Plant Biochemistry and Biotechnology 17: 111-126.

Sakin, M., Sayaslan, A., Duzdemir, O. \& Yuksel, F. 2011. Quality characteristics of registered cultivars and advanced lines of durum wheats grown in different ecological regions of Turkey. Canadian Journal of Plant Science 91: 261-271.

Shahzad, Z., Rouached, H. \& Rakha, A. 2014. Combating mineral malnutrition through iron and zinc biofortification of cereals. Comprehensive Reviews in Food Science and Food Safety 13: 329-346.

Shewry, P.R. 2009. Wheat. Journal of Experimental Botany 60: 1537-1553.

Shewry, P.R. \& Ward, J.L. 2012. Exploiting genetic variation to improve wheat composition for the prevention of chronic diseases. Food and Energy Security 1: 47-60.

Shi, J., Wang, H., Schellin, K., Li, B., Faller, M., Stoop, J.M., Meeley, R.B., Ertl, D.S., Ranch, J.P. \& Glassman, K. 2007. Embryo-specific silencing of a transporter reduces phytic acid content of maize and soybean seeds. Nature Biotechnology 25: 930-937.

Simić, A., Sredojević, S., Todorović, M., Đukanović, L. \& Radenović, C. 2004. Studies on the relationship between content of total phenolics in exudates and germination ability of maize seed during accelerated aging. Seed Science and Technology 32: 213-218.

Singh, P.K. 2008. Significance of phytic acid and supplemental phytase in chicken nutrition: a review. World's Poultry Science Journal 64: 553-580.

Singh, A., Reimer, S., Pozniak, C.J., Clarke, F.R., Clarke, J.M., Knox, R.E. \& Singh A.K. 2009. Allelic variation at Psy1-A1 and association with yellow pigment in durum wheat grain. Theoretical and Applied Genetics 118: 1539-1548.

Statsoft, 2009. Electronic Statistics Textbook. $9^{\text {th }}$ ed. Tulsa, Oklahoma, USA: StatSoft Inc. http://www.statsoft.com/textbook/.

Vences, F.J., Vaquero, F., Garcia, P. \& Benito, C. 1982. The chromosomal location of factors determining the presence of phenolic compounds in wheat (Triticum aestivum L.). Theoretical and Applied Genetics 61: 125-128.

Vella, S. \& Value Added Wheat CRC 2007. Finding the QTLs Responsible for the Low Phytic Acid Phenotype in Triticum aestivum (Vulcan $x$ Kewell population).VAWCRC Reports 73, Sidney, Australia: Value Added Wheat CRC. 21 p.

Vieira dos Santos, C. \& Rey, P. 2006. Plant thioredoxins are key factors in oxidative stress response. Trends in Plant Science 11: 329-334.

Yan, W. \& Rajcan, I. 2002. Biplot evaluation of test sites and trait relations of soybean in Ontario. Crop Science 42: 11-20.

Yan, W. \& Tinker, N.A. 2006. Biplot analysis of multienvironment trial data: Principles and applications. Canadian Journal of Plant Science 86: 623-645.

Ye, X., Al-Babili, S., Kloti, A., Zhang, J., Lucca, P., Beyer, P. \& Potrykus, I. 2000. Engineering the provitamin A ( $\beta$-carotene) biosynthetic pathway into (carotenoid-free) rice endosperm. Science 287: 303-305.

Yenagi, S.N. \& Basarkar, P.W. 2008. Antioxidant contents of whole grain cereals of North Karnataka. Karnataka Journal of Agricultural Sciences 21: 602-603.

Yeum, K.J. \& Russell, R.M. 2002. Carotenoid bioavailability and bioconversion. Annual Review of Nutrition 22: 483-504.

Zhao, H.J., Liu, Q.L., Fu, H.W., Xu, X.H., Wu, D.X. \& Shu, Q.Y. 2008. Effect of non-lethal low phytic acid mutations on grain yield and seed viability in rice. Field Crop Research 108: 206-211.

Zhou, K. \& Yu, L. 2004. Antioxidant properties of bran extracts from Trego wheat grown at different locations. Journal of Agricultural and Food Chemistry 52: 1112-1117.

Žilić, S., Hadži-Taškovic Šukalović, V., Srebrić, M., Dodig, D., Maksimović, M., Mladenović Drinić, S. \& Crevar, M. 2009. Chemical compositions as quality parameters of ZP soybean and wheat genotypes. Genetika-Belgrade 41: 297-308.

Žilić, S., Hadži-Tašković Šukalović, V., Dodig, D., Maksimović, V., Maksimović, M. \& Basić, Z. 2011. Antioxidant activity of small grain cereals caused by phenolics and lipid soluble antioxidants. Journal of Cereal Science 54: 417-424.

Žilić, S., Hadži-Tašković Šukalović, V., Dodig, D., Maksimović, V. \& Kandić, V. 2013. Soluble free phenolic compound contents and antioxidant capacity of bread and durum wheat genotypes. Genetika-Belgrade 45: 87-100. 